Cleiton de Oliveira e Valéria Virgínia Lopes analisam artigos divulgados em periódicos científicos. Foram consultados 107 títulos de periódicos acadêmicos, publicados em diferentes localidades do país, tendo sido localizados 217 artigos sobre gestão, autonomia escolar e órgãos colegiados, publicação essa concentrada em 45 periódicos. Torna-se mais evidente a concentração das publicações em certos espaços de divulgação, quando se verifica que 53\% desses artigos foram publicados em apenas seis periódicos, reconhecidos pelos autores como aqueles que direcionam suas publicações à administração educacional e à análise de políticas públicas. Como nas demais fontes analisadas, o tema gestão, com destaque para a perspectiva democrática, é o mais numeroso.

A coletânea, por meio de seus capítulos, articulados entre si, possibilita ao leitor a apropriação da metodologia utilizada para a elaboração do estado da arte e dos resultados das análises empreendidas pelos autores. Além do interesse que pode suscitar aos gestores públicos e educadores em geral, constitui consulta obrigatória para aqueles que se dedicam a estudos sobre gestão e administração educacional. Traz observações e considerações contundentes, que decorrem dos documentos analisados, e remetem desde a um debate conceitual acerca da noção de democracia, “palavra de ordem” presente em grande quantidade de estudos, até a questões de natureza metodológica. Para ilustrar e instigar a leitura da coletânea, são reproduzidas duas observações que se originaram das análises da produção: a polissemia do termo gestão democrática "levou parte dos estudos a confundir o ‘tema' com o próprio ‘objeto de pesquisa’”; “técnicas [são] confundidas com opções metodológicas”.

Ao desvendar características dos estudos divulgados no período de 2000 a 2008, que em sua maioria têm origem nos programas de pós-graduação, os autores instigam a reflitir sobre condições e contradições que permeiam a produção de conhecimento na área da educação.

SANDRA ZÁKIA SOUSA sanzakia@usp.br

Professora da Faculdade de Educação da Universidade de São Paulo e do Mestrado em Educação da Universidade Cidade de S. Paulo.

\title{
Escola Pública e Pobreza no Brasil: a Ampliação para Menos eVeline algebaile
}

RIO DE JANEIRO: LAMPARINA, 2009, 352 p.

Este livro é fruto da tese de doutorado de Eveline Algebaile, defendida no Programa de Pós-Graduação em Educação da Universidade Federal Fluminense - UFF -, com a orientação do Professor Victor Valla. O prefácio do professor Gaudêncio Frigotto enfatiza a necessidade de pensar a educação 
no Brasil a partir da sua realidade socioeconômica e política e do projeto de sociedade que se quer construir e do que está em construção.

A tese de Eveline Algebaile é que a ampliação do sistema de ensino nos anos 1990 foi embasada não por uma proposta educacional consistente, mas por haver um entendimento de que a educação é um fator minimizador de riscos e de tensões sociais. Para atender a essa concepção não era necessário implementar um sistema de ensino sofisticado, mas utilizar a estrutura da rede de escolas públicas para a prestação de serviços de assistência social, com o objetivo de atenuar a pobreza.

A pesquisa assevera que a pretensa qualidade da escola pública, que teria sido tragada pelo seu processo de expansão, na realidade nunca se materializou fora das fronteiras dos centros mais abastados do país. Sob essa ótica, "o descompasso entre quantidade e qualidade”, uma das principais expressões utilizadas para referir o problema da escola pública atual, é, com efeito, uma das "expressões do lugar secundário que as funções educativas ocupam na formação da escola pública brasileira”.

Não por acaso a reforma de ensino dos anos 1990 diagnosticou a crise do ensino público como um problema de concepção da escola pública e de formação do professor. Efetuada a "modernização da administração pública, da escola e do professor”, a crise estaria, se não equacionada, resolvida em seus elementos constitutivos.

A escola pública, assim, é examinada de modo desvinculado de sua constituição histórica e de sua articulação com o projeto político, econômico e social brasileiro. A escola, expressão do atraso, precisa se modernizar ou ser modernizada de cima para baixo, para que sua crise possa ser superada.

Em muitos casos, contudo, a expansão do acesso à escola não esteve associada à de sua estrutura física, muito menos ao aumento do quadro de professores, mas à reorganização do espaço escolar.

Algebaile chama a atenção para uma política educacional oculta, que atua nas brechas da legislação, beneficiada pela deficiência do sistema de ensino. É desse modo que o mínimo previsto se transforma no máximo ofertado. Isso ocorre não só com a carga horária prevista em lei, mas também com os espaços em que o processo de ensino-aprendizagem se consubstancia. É dentro dessa dinâmica que o processo de expansão escolar passa a dialogar com ações de manipulação de tempo e de espaço que, mesmo não sendo previstas legalmente, vêm se materializando em diferentes administrações.

Um exemplo de manipulação de tempo é a forma pela qual muitos municípios se adequaram ao aumento da carga horária prevista na Lei de Diretrizes e Bases da Educação Nacional n. 9.394/1996.

Como o incentivo à municipalização ocorreu pela transferência de recursos aos municípios, condicionada ao número de matrículas (censo 
escolar), quanto maior a capacidade de o município expandir o número de matrículas, maior é o repasse de recursos efetuado pelo fundo de manutenção do ensino.

A manipulação do tempo utilizada por algumas administrações municipais para ampliar a captação de recursos (aumento do número de matrículas), sem ampliar a rede de escolas públicas, foi a criação de um terceiro turno diurno. $\mathrm{O}$ "turno da fome" (das 11 às 14 horas), denominado assim por ocorrer no horário do almoço.

O perverso é que esse turno acaba incorporando, na maioria dos casos, os alunos mais pobres, uma vez que suas famílias se dão conta de que no horário há oportunidade de o filho receber uma refeição completa. Essa modalidade de manipulação do tempo não é novidade, mas uma atualização sobre novas bases, pois mesmo municípios que já haviam implantado jornada escolar superior ao mínimo legal (quatro horas) reorganizaram sua carga horária mínima para quatro horas diárias, para viabilizar a criação de mais um turno diurno.

Na análise de uma professora entrevistada, a aparente redução da carga horária dos professores é apresentada como um prêmio por sua capacidade de controlar a turma sem pausa para descanso. A compressão dos turnos, no entanto, não tem efeito somente na redução da carga horária do professor e dos alunos, mas também na organização do trabalho pedagógico. Como toda a escola é organizada com o objetivo de otimizar a capacidade de ministrar aulas, observa-se a carência de espaço físico para outras práticas pedagógicas e, mais ainda, para reuniões de planejamento e avaliação.

As ações de manipulação do espaço se materializam na instalação de escolas em locais inadequados, muitas vezes improvisados. E mesmo espaços construídos especialmente para ser utilizados como áreas antes reservadas a biblioteca, esportes, copa etc., são transformados em sala de aula para atender à dinâmica da expansão. A lógica que orienta o recurso à adaptação é a necessidade de garantir o funcionamento da escola e a oferta de vagas, aliados à noção de que o processo de ensino-aprendizagem pode ocorrer em qualquer espaço físico.

A manipulação do espaço escolar se manifesta no uso de instalações mal adaptadas, no aluguel de espaços inapropriados, na criação de anexos etc. Uma das "vantagens" da criação de anexos é a possibilidade da expansão de vagas sem que seja necessária a nomeação de um corpo diretivo e pedagógico, tampouco a organização de instâncias participativas que contribuam para a gestão democrática da escola pública, como os conselhos escolares.

\section{MARIA DA CONCEIÇÃO CALMON ARRUDA conceicaoarruda2010@hotmail.com}

Professora adjunta da Universidade Federal Rural do Rio de Janeiro e doutora em Educação pela Pontifícia Universidade Católica do Rio de Janeiro. 